\title{
Effect of Weed Management Practices in Chrysanthemum (Dendranthema grandiflora T.) Under Tarai Conditions of Uttarakhand
}

\author{
Ajit Kumar ${ }^{1}$, Manoj Kumar ${ }^{1}$, Sanchita Ghosh ${ }^{1 *}$, Tripti Tewari ${ }^{2}$ and S.B. Bhardwaj ${ }^{2}$ \\ ${ }^{1}$ Department of Horticulture, ${ }^{2}$ College of Basic Sciences and Humanities, G. B. Pant University \\ of Agriculture and Technology, Pantnagar, Uttarakhand, India \\ *Corresponding author
}

Keywords

Chrysanthemum,

Garden beauty,

Herbicide,

Vegetative and

flowering

attributes, Vase life, Weed count.

Article Info

Accepted:

23 June 2017

Available Online:

10 August 2017

\section{A B S T R A C T}

Weed management in crops through hand weeding is facing a tough challenge in many developing countries like India where workers are migrating from rural to urban areas in search of better job and lifestyle opportunities. Manual weeding option is facing acute shortage of labour. The present investigation was therefore carried out to ascertain the influence of weed management practices on growth and flowering of chrysanthemum variety Garden Beauty. The experiment consisted of seven treatments comprising of hand weeding, herbicides, weed free check and weedy check replicated thrice in randomized block design. Among the weed control treatments, the minimum weed count (35.50), fresh weight $(22.78 \mathrm{~g})$, and dry weight $(7.51 \mathrm{~g})$ of weeds $/ \mathrm{m}^{2}$ were recorded with the treatment pendimethalin@1.0 kg a.i. per ha at 75 days after transplanting. Various vegetative and flowering characteristics like maximum plant height at first bud appearance, number of branches per plant, plant spread, minimum days taken to colour break stage, days taken to full bloom stage, duration of flowering, number of flowers per plant, flower diameter, weight of loose flowers per plant, yield of loose flowers per hectare and vase life were improved at the application of pendimethalin @ 1.0 kg a.i.per ha.

\section{Introduction}

Chrysanthemum

(Dendranthema grandiflora T.) is one of the most widely cultivated herbaceous perennial plant belonging to family Asteraceae and commonly known as 'Autumn Queen' or 'Queen of East'. In cut flower trade, chrysanthemum ranks second after rose at the Dutch auctions, which is a good indicator of its global trade. In India, chrysanthemum occupies a place of pride, both as commercial flower crop and as a popular exhibition flower. It is very popular as cut flower, loose flower as well as pot plant. Success in any crop production technology depends on thorough weed management practices. Weeds are of special significance when the chrysanthemum is grown in the field for commercial production. Weeds cause heavy damage to this crop by competing with main plants for water, nutrients, light and space besides acting as alternate hosts to a number of pathogens and pests. Hence, for protection of this commercially important crop, proper weed control is of utmost significance. In 
India, about 6,000 tons of herbicides were used for weed control, mainly in irrigated crops (about $77 \%$ on wheat and rice) and on plantations (about 10\%) in the beginning of this century (Bhat and Chopra, 2006). Improved weed control with herbicides has the potential greatly to improve crop yields in many developing countries in the near future (Masthan et al., 1989). The world is rushing towards adopting herbicides to manage weeds in agricultural crop production. Benefits of herbicides over conventional weeding practice forced developed countries to consume 90\%, Latin America 70\%, Europe 67\%, Asia 84\% and Africa 94\% more herbicides after 15 years of initiation (WAP, 2014). The use of herbicides has gained impetus from the general rise in farm wages as a consequence of overall economic growth and growth in non-farm employment opportunities, particularly in Asia where adequate non-chemical controls for weeds are not available, and herbicide use is increasing dramatically as a result of rising opportunity costs of labour across the developing world (Pingali and Gerpacio, 1997). Since manual weeding is a time and labour consuming affair, an alternative method would be to use herbicides. Therefore, the present investigation was carried out to assess the effect of pre- and post-emergence herbicides among other weed management practices for quality flower production in chrysanthemum.

\section{Materials and Methods}

The investigation was conducted at Model Floriculture Centre, G.B. Pant University of Agriculture and Technology, Pantnagar located in Tarai regions of Uttarakhand in foothills of Himalaya during 2014-15 and 2015-16. The experiment comprised of seven treatments viz., atrazin @ $0.75 \mathrm{~kg}$ a.i. per ha $\left(\mathrm{T}_{1}\right)$, pendimethalin @ $1.0 \mathrm{~kg}$ a.i. per ha $\left(\mathrm{T}_{2}\right)$, oxyfluorfen @ $0.2 \mathrm{~kg}$ a.i. per ha $\left(\mathrm{T}_{3}\right)$, bispyribac-sodium @ 25 g per ha $\left(\mathrm{T}_{4}\right)$, three hand weedings $\left(\mathrm{T}_{5}\right)$ at 25,50 and 75 days after transplanting (DAT), weed free check $\left(\mathrm{T}_{6}\right)$ and weedy check $\left(\mathrm{T}_{7}\right)$ used in a randomized block design with three replications. Good quality and uniform sized rooted terminal cuttings were planted in the field having individual plot size of $1 \mathrm{~m} \mathrm{x} 1 \mathrm{~m}$ with a spacing of $30 \mathrm{~cm} \times 30 \mathrm{~cm}$. All the recommended package of practices were followed. A spacing of $50 \mathrm{~cm}$ between two sub-plots was provided for irrigation channels and working space. Observations were recorded on two main aspects vis-a-vis weed parameters and plant growth parameters. Weed parameters included types of weeds, weed count per square meter, fresh and dry weight of weeds. The plant growth parameters included plant height at first flower bud appearance, number of primary branches per plant, plant spread (North-South and EastWest), days taken to colour break stage from transplanting, days taken to full bloom stage, duration of flowering, number of flowers per plant, flower diameter, weight of loose flowers per plant, yield of loose flowers per hectare and vase life. In hand weeding treatment, weeds were removed manually at 30, 45 and 90 days after transplanting. The data were statistically analyzed by using randomized block design (Gomez and Gomez, 1984).

\section{Results and Discussion}

\section{Weed parameters}

In the experimental field, different types of weeds viz., nut grass (Cyperus rotundus), asthma weed (Euphorbia hirta), hairy crabgrass (Digitaria sanguinalis) and Indian cudweed/tiny cudweed (Gnaphalium indicum) were found predominantly throughout the growing period. The data presented in Table 1 reveal that lowest number of weeds (35.50) were recorded at 75 days after transplanting in the treatment pendimethalin @ $1.0 \mathrm{~kg}$ a.i. per 
ha which is statistically at par with treatment atrazin@ $0.75 \mathrm{~kg}$ a.i. per ha (40.76) and bispyribac-sodium @ 25 g/ha (45.56) followed by oxyfluorfen@ $0.2 \mathrm{~kg}$ a.i. per ha (48.00). Whereas, the highest number of weeds (143.03) were found in weedy check. All the treatments significantly reduced the fresh weight of weeds as compared to weedy check. Minimum fresh weight of weeds was observed with pendimethalin @ $1.0 \mathrm{~kg}$ a.i. per ha at various stages of crop growth. The minimum dry weight of weeds $(7.51 \mathrm{~g})$ was recorded in the treatment pendimethalin @ $1.0 \mathrm{~kg}$ a.i. per ha at 75 DAT which is statistically at par with treatment bispyribacsodium@25 g/ha (9.62 g), oxyfluorfen@ $0.2 \mathrm{~kg}$ a.i. per ha $(10.11 \mathrm{~g})$ and atrazin @ 0.75 $\mathrm{kg}$ a.i. per ha (15.10 g), while maximum dry weight of weeds $(30.20 \mathrm{~g})$ was recorded in weedy check. The minimum dry weight of weeds was recorded in the treatment pendimethalin@1.0 kg a.i.per ha. It may be due to the lesser number of weeds, rapid depletion of carbohydrate reserves of weeds though rapid respiration. Similar findings were also reported by Tripathy et al., (2015) in chrysanthemum.

\section{Vegetative growth and flowering attributes}

Various treatments were found to have significant effect on the vegetative growth and flowering parameters as compared to unweeded check (Tables 1 and 2). The maximum plant height $(36.53 \mathrm{~cm})$ at first flower bud appearance was recorded in the treatment pendimethalin @ $1.0 \mathrm{~kg}$ a.i. per ha followed by bispyribac-sodium @ $25 \mathrm{~g} / \mathrm{ha}$ $(33.80 \mathrm{~cm})$, while minimum plant height $(26.26 \mathrm{~cm})$ was recorded in weedy check. The maximum number of branches per plant (8.40) were found in the treatment pendimethalin @ 1.0 $\mathrm{kg}$ a.i. per ha which is at par with treatment bispyribac-sodium @ 25 g/ha (7.46) and oxyfluorfen @ $0.2 \mathrm{~kg}$ a.i. per ha (7.00) followed by atrazin @ $0.75 \mathrm{~kg}$ a.i. per ha (6.46), whereas, minimum number of branches per plant (4.80) were found in weedy check. Plant spread in N$\mathrm{S}$ direction was observed maximum (34.26 $\mathrm{cm})$ in the treatment pendimethalin @ $1.0 \mathrm{~kg}$ a.i. per ha which is at par with treatment bispyribac-sodium @ 25 g/ha (31.67 cm), and minimum plant spread $(27.00 \mathrm{~cm})$ was recorded in weedy check. However, statistically non-significant differences were observed among various weed control treatments. Plant spread in E-W direction was observed maximum $(31.86 \mathrm{~cm})$ in the treatment pendimethalin@1.0 kg a.i. per ha which is at par with bispyribac-sodium @ 25 g/ha (31.00 cm), oxyfluorfen @ $0.2 \mathrm{~kg}$ a.i. per ha $(29.86 \mathrm{~cm})$ and weed free $(27.86 \mathrm{~cm})$ followed by atrazin @ $0.75 \mathrm{~kg}$ a.i per ha $(27.46 \mathrm{~cm})$ while minimum plant spread $(24.73 \mathrm{~cm})$ was recorded in weedy check. The decrease in the plant height in weedy check may be due to unavailability of sufficient nutrients, space and moisture at critical stages to plant for its luxuriant growth.

The branches are the skeletal structure of the plant and were significantly influenced by the different weed control treatments. The significantly maximum number of branches per plant and plant spread were recorded in the plants treated with pendimethalin @ $1.0 \mathrm{~kg}$ a.i. per ha. This might be due to pendimethalin at this concentration helped to keep the weeds below the threshold level. Effective weed control might have increased the capacity of the crop in utilizing soil moisture, light, nutrient and carbon dioxide in building new tissues that accounted for improving the vegetative growth (Mekki et al., 2010), thereby, this herbicides in turn was effective in allowing the plants to have higher plant growth. Similar findings were also recorded by Patil (2006) in gerbera, Kadam et al., (2014) in gladiolus and Sharma et al., (2014) in chrysanthemum.

Early flowering is an ideal flowering attribute among all ornamental crops because it favours off season production resulting in better market prices for farmers. Findings of 
this investigation reported that plants sprayed with pendimethalin @ $1.0 \mathrm{~kg}$ a.i. per ha took minimum days taken to colour break stage (50.13) as well as days to full bloom stage (75.86) from transplanting and these traits were delayed most (71.70 and 87.40 days, respectively) in weedy check which was significantly higher than all other treatments. This might be due to herbicidal application which maintained the weed free conditions and thus allowed the chrysanthemum plants to exploit the available soil resources potentially resulting into early flowering.

Maximum days (87.40) recorded in weedy check might be due to severe infestation of weeds which resulted in competition for moisture, nutrients, sunshine, aeration and space. These findings are in corroboration with the findings of Sharma et al., (2014) in chrysanthemum.

Table.1 Effect of different weed management practices on weeds in chrysanthemum field (2-year pooled data)

\begin{tabular}{|c|c|c|c|c|c|c|c|}
\hline \multirow[t]{2}{*}{ Treatments } & \multirow{2}{*}{$\begin{array}{l}\text { No. of weeds } \\
\mathrm{m}^{-2} \text { at } 75 \text { DAT } \\
\left(\text { count } \mathbf{m}^{-2}\right)\end{array}$} & \multicolumn{3}{|c|}{ Fresh weight of weeds $\mathrm{m}^{-2}(\mathrm{~g})$} & \multicolumn{3}{|c|}{ Dry weight of weeds $\mathrm{m}^{-2}(\mathrm{~g})$} \\
\hline & & 25 DAT & 50 DAT & 75 DAT & 25 DAT & 50 DAT & 75 DAT \\
\hline $\mathrm{T}_{1}$ & 40.76 & 10.81 & 19.44 & 26.09 & 3.68 & 6.39 & 15.10 \\
\hline $\mathrm{T}_{2}$ & 35.50 & 8.57 & 17.81 & 22.78 & 2.83 & 5.92 & 7.51 \\
\hline $\mathrm{T}_{3}$ & 48.00 & 12.86 & 24.71 & 30.65 & 4.25 & 8.27 & 10.11 \\
\hline $\mathrm{T}_{4}$ & 45.56 & 12.98 & 22.20 & 29.11 & 4.28 & 7.41 & 9.62 \\
\hline $\mathrm{T}_{5}$ & 117.66 & 42.70 & 60.58 & 75.30 & 14.91 & 19.98 & 24.84 \\
\hline $\mathrm{T}_{6}$ & - & - & - & - & - & - & - \\
\hline $\mathrm{T}_{7}$ & 143.03 & 50.32 & 74.06 & 91.56 & 16.05 & 24.65 & 30.20 \\
\hline SEm \pm & 3.50 & 1.28 & 3.32 & 2.26 & 0.67 & 1.06 & 2.84 \\
\hline $\mathrm{CD}$ at $5 \%$ & 11.18 & 4.02 & 10.46 & 7.11 & 2.11 & 3.34 & 8.94 \\
\hline
\end{tabular}

Where $\mathrm{T}_{1}=$ Atrazin @ $0.75 \mathrm{~kg}$ a.i. per ha; $\mathrm{T}_{2}=$ Pendimethalin @ $1.0 \mathrm{~kg}$ a.i. per ha; $\mathrm{T}_{3}=$ Oxyfluorfen @ $0.2 \mathrm{~kg}$ a.i. per ha; $\mathrm{T}_{4}=$ Bispyribac-sodium @ $25 \mathrm{~g}$ per ha; $\mathrm{T}_{5}=$ Three hand weedings at 25,50 and 75 days after transplanting $(\mathrm{DAT}) ; \mathrm{T}_{6}=$ Weed free check and $\mathrm{T}_{7}=$ Weedy check

Table.2 Effect of different weed management practices on growth of in chrysanthemum (2-year pooled data)

\begin{tabular}{|c|c|c|c|c|}
\hline \multirow{2}{*}{ Treatment } & Plant height at first flower bud & \multicolumn{2}{|l|}{$\begin{array}{l}\text { Number } \\
\text { branches/plant }\end{array}$} & \multicolumn{2}{|c|}{ Plant spread (cm) } \\
\cline { 3 - 5 } & appearance (cm) & 6.46 & N-S & E-W \\
\hline $\mathrm{T}_{1}$ & 31.33 & 8.40 & 31.20 & 27.46 \\
\hline $\mathrm{T}_{2}$ & 36.53 & 7.00 & 30.87 & 31.86 \\
\hline $\mathrm{T}_{3}$ & 33.53 & 7.46 & 31.67 & 29.86 \\
\hline $\mathrm{T}_{4}$ & 33.80 & 5.93 & 28.93 & 25.13 \\
\hline $\mathrm{T}_{5}$ & 29.46 & 5.80 & 29.53 & 27.86 \\
\hline $\mathrm{T}_{6}$ & 27.86 & 4.80 & 27.00 & 24.73 \\
\hline $\mathrm{T}_{7}$ & 26.26 & 0.61 & 1.49 & 1.33 \\
\hline $\mathrm{SEm} \pm$ & 0.32 & 1.87 & $\mathrm{NS}$ & 4.09 \\
\hline $\mathrm{CD}$ at $5 \%$ & 0.979 & $1.0 \mathrm{~g}$ & $\mathrm{O}$ \\
\hline
\end{tabular}

Where $\mathrm{T}_{1}=$ Atrazin @ $0.75 \mathrm{~kg}$ a.i. per ha; $\mathrm{T}_{2}=$ Pendimethalin @1.0 kg a.i. per ha; $\mathrm{T}_{3}=$ Oxyfluorfen @ $0.2 \mathrm{~kg}$ a.i. per ha; $\mathrm{T}_{4}=$ Bispyribac-sodium @ $25 \mathrm{~g}$ per ha; $\mathrm{T}_{5}=$ Three hand weedings at 25,50 and 75 days after transplanting $\left(\right.$ DAT); $\mathrm{T}_{6}=$ Weed free check and $\mathrm{T}_{7}=$ Weedy check 
Table.3 Effect of different weed management practices on flowering of in chrysanthemum (2-year pooled data)

\begin{tabular}{|l|l|l|l|l|l|l|l|l|}
\hline Treatment & $\begin{array}{l}\text { Days to } \\
\text { colour } \\
\text { break } \\
\text { stage }\end{array}$ & $\begin{array}{l}\text { Days } \\
\text { taken to } \\
\text { full } \\
\text { bloom } \\
\text { stage }\end{array}$ & $\begin{array}{l}\text { Duration } \\
\text { of } \\
\text { flowering } \\
\text { (days) }\end{array}$ & $\begin{array}{l}\text { Number } \\
\text { of } \\
\text { flowers/pl } \\
\text { ant }\end{array}$ & $\begin{array}{l}\text { Flower } \\
\text { diameter } \\
(\mathbf{c m})\end{array}$ & $\begin{array}{l}\text { Weight of } \\
\text { loose } \\
\text { flowers/pl } \\
\text { ant }(\mathbf{g})\end{array}$ & $\begin{array}{l}\text { Yield } \\
\text { loose } \\
\text { flowers/ha } \\
(\mathbf{q})\end{array}$ & $\begin{array}{l}\text { Vase } \\
\text { (Days) }\end{array}$ \\
\hline $\mathrm{T}_{1}$ & 54.27 & 80.93 & 30.11 & 21.40 & 8.25 & 29.75 & 21.33 & 12.99 \\
\hline $\mathrm{T}_{2}$ & 50.13 & 75.86 & 31.55 & 26.67 & 8.65 & 37.07 & 26.67 & 16.89 \\
\hline $\mathrm{T}_{3}$ & 58.60 & 82.20 & 28.44 & 22.27 & 8.00 & 31.02 & 22.13 & 14.10 \\
\hline $\mathrm{T}_{4}$ & 57.53 & 80.00 & 28.22 & 24.60 & 7.91 & 34.27 & 24.53 & 11.99 \\
\hline $\mathrm{T}_{5}$ & 68.33 & 84.13 & 23.88 & 13.33 & 7.41 & 18.52 & 13.07 & 11.22 \\
\hline $\mathrm{T}_{6}$ & 63.30 & 84.66 & 22.78 & 18.13 & 7.70 & 25.20 & 18.13 & 15.89 \\
\hline $\mathrm{T}_{7}$ & 71.70 & 87.40 & 19.89 & 12.13 & 6.92 & 16.90 & 12.00 & 8.55 \\
\hline $\mathrm{SEm} \pm$ & 2.22 & 1.27 & 0.66 & 1.79 & 0.35 & 2.49 & 1.73 & 0.31 \\
\hline $\mathrm{CD}$ at $5 \%$ & 6.85 & 3.91 & 2.05 & 5.54 & $\mathrm{NS}$ & 7.68 & 5.34 & 0.96 \\
\hline
\end{tabular}

Where $\mathrm{T}_{1}=$ Atrazin @ $0.75 \mathrm{~kg}$ a.i. per ha; $\mathrm{T}_{2}=$ Pendimethalin @ $1.0 \mathrm{~kg}$ a.i. per ha; $\mathrm{T}_{3}=$ Oxyfluorfen @ $0.2 \mathrm{~kg}$ a.i. per ha; $\mathrm{T}_{4}=$ Bispyribac-sodium @ $25 \mathrm{~g}$ per ha; $\mathrm{T}_{5}=$ Three hand weedings at 25, 50 and 75 days after transplanting $(\mathrm{DAT}) ; \mathrm{T}_{6}=$ Weed free check and $\mathrm{T}_{7}=$ Weedy check

Duration of flowering recorded from peak flowering up to the stage till flowers remain presentable, was found maximum (31.55 days) in the treatment pendimethalin @ $1.0 \mathrm{~kg}$ a.i. per ha which is statistically at par with treatment atrazin@0.75 kg a.i.per ha (30.11 days) followed by oxyfluorfen @ $0.2 \mathrm{~kg}$ a.i. per ha (28.44 days) and minimum flowering duration (19.89 days) was recorded in weedy check (Table 3). Maximum flowering duration was recorded in pendimethalin @ $1.0 \mathrm{~kg}$ a.i. per ha.

This can be attributed to availability of nutrients at critical growth stage of plants by reduced weed counts and competition for moisture, nutrients and space which resulted in higher flowering duration. The increase in flowering duration can also be attributed to increased protein synthesis, rapid nutrient mobilization and prevention of chlorophyll degradation due to sufficient amount of nutrient availability. The maximum flowering duration in the weed management treatments can be attributed to higher chlorophyll content and photosynthetic rate due to effective control of weeds at critical crop-weed competition stage
(Channappagoudar et al., 2006). While minimum flowering duration was recorded in weedy check. This might be due to greatest weed interferences in weedy check. Similar findings were also reported by Kori and Patil (2003) in gladiolus and Kocira and Laskowska (2006) in acidenthera. Maximum number of flowers per plant (26.67) were observed in pendimethalin@1.0 kg a.i. per ha, which is statistically at par with bispyribac-sodium @ 25 g per ha (24.60), oxyfluorfen @ $0.2 \mathrm{~kg}$ a.i. per ha (22.27), whereas, minimum number of flowers (12.13) were recorded in weedy check.

Exhibition quality of a flower is determined by its shape and size. Bigger the bloom means having better display quality and attractiveness. This study showed that maximum flower diameter $(8.65 \mathrm{~cm})$ and weight of loose flowers per plant $(37.07 \mathrm{~g})$ were observed in pendimethalin @ $1.0 \mathrm{~kg}$ a.i. per ha, which is statistically at par with bispyribac-sodium @ $25 \mathrm{~g}$ per ha, oxyfluorfen@0.2 kg a.i. per ha, followed by atrazin@ $0.75 \mathrm{~kg}$ a.i. per ha (Table 3). Minimum flower diameter $(6.92 \mathrm{~cm})$ and weight of loose flowers per plant $(16.90 \mathrm{~g})$, 
was obtained in weedy check (Table 3). Higher flower yield might also be attributed to the availability of nutrients, moisture and less competition from weeds for sunlight and space. The lowest flower yield was obtained in weedy check. This might be due to severe weed competition which ultimately resulted in lower yield. Similar, findings were also observed by Tripathy et al., (2015) in chrysanthemum. Maximum yield of loose flowers per hectare $(26.67 \mathrm{q})$ was recorded in the pendimethalin @1.0 kg a.i. per ha, which is statistically at par with bispyribac-sodium @ 25 g per ha (24.53 q) and oxyfluorfen @ $0.2 \mathrm{~kg}$ a.i. per ha $(22.13 \mathrm{q})$ while minimum weight of loose flowers per hectare $(12.00 \mathrm{q})$ was obtained in weedy check (Table 3 ).

Vase life is an important quality parameter for cut flowers. It is evident from Table 3 that maximum days to half of flowers show wilting (16.89) were found in flowers harvested from the weed free check plots followed by pendimethalin @ $1.0 \mathrm{~kg}$ a.i. per ha (15.89). However, minimum days to half of flowers show wilting (8.55) were seen in weedy check. From the results, it is clear that in weedy check, the crop might have been adversely affected by weeds due to heavy competition for nutrients, water, light, vertical and horizontal space which leads to poor growth and unacceptable quality of flowers which ultimately reduces the vase life of flowers. Similar findings were also reported by Rao et al., (2014) in gladiolus.

On the basis of the present investigation, it can be concluded that all the weed control treatments proved advantageous over weedy check. However, pendimethalin@1.0 kg a.i. per ha gave better results for various traits than rest of the treatments which can be tried for efficient control of the weeds for higher flower yield in chrysanthemum variety Garden Beauty.

\section{References}

Bhat, S. R., and Chopra, V. L. 2006. Choice of technology for herbicide resistant transgenic crops in India: examination of issues. Current Sci. 91(4): 435-438.

Channappagoudar, B. B., Biradar, N. R., Bharamagoudar, T. D. and Rokhade, C. J. 2006. Physiological studies on weed control efficiency of different herbicides in sunflower. Karnataka J. Agric. Sci. 21(2): 165-167.

Gomez, K. A., and Gomez, A. A. 1984. Statistical Procedures for Agricultural Research. John Wiliey and Sons, Inc. New York. pp. 680.

Kadam, G. B., Kumar, G., Saha, T. N., Kumar, R., Tiwari, A. K. and Kumar, R. 2014. Evaluation of pre-emergence herbicides in gladiolus (Gladiolus grandiflorus). Indian J. Agric. Sci. 84(12): 1546-1549.

Kocira, A., and Laskowska, H. 2006. Influence of herbicides and organic mulches on yield and quality of flowers of Acidanthera bicolor. Acta Sci. Poland, 5(1): 37-44.

Kori, V. K., and Patil, V. S. 2003. Effect of weed control treatments on flowering in gladiolus. J. Orn. Hort. New Series. 6(4): 397-399.

Masthan, S. C., Reddy, K. A., Reddy, T. R. and Rao, L. J. 1989. Increasing the productivity of rice, maize and groundnut in farmers' fields in Andhra Pradesh through weed control. Pesticides, 23(6): 42-44.

Mekki, B. B., Faida, A. A. and Kowthar, G. 2010. Effect of weed control treatments on yield and seed quality of some Canola cultivars and associated weeds in newly reclaimed sandy soils. American-Eurasian J. Agric. Env. Sci. 7(2): 90-91.

Patil, M. S., 2006. Effect of integrated weed management practices on vegetative 
reproductive and yield parameters in gerbera. Karnataka J. Agric. Sci. 19(3): 649-652.

Pingali, P. L., and Gerpacio, R. V. 1997. Towards reduced pesticide use for cereal crops in Asia. CIMMYT Working Paper, 97-104.

Rao, K. D., Kameswari, P. L., Girwani, A. and Rani, T. B. 2014. Chemical weed management in gladiolus (Gladiolus grandiflorus). Agric. Sci. Digest, 34(3): 194-198.

Sharma, G., Shrivastava, A., Dhakre, D. S. and Singh, D. P. 2014. Effect of weed management practices in chrysanthemum (Dendranthema grandiflora T.) under Chhattisgarh plains agro-climatic condition. Int. J. Bio-reso. Stress Management. 5(3): 400-403.

Tripathy, L., Dash, S. K., Dash, D. K. and Murmu, S. 2015. Effect of chemicals on weed control in spray chrysanthemum. J. Crop and Weed, 11: 217-219.

WAP (World Agricultural Pesticides) 2014. Industry market research for business leaders, strategists, decision makers. pp. 399-411.

\section{How to cite this article:}

Ajit Kumar, Manoj Kumar, Sanchita Ghosh, Tripti Tewari and Bhardwaj S. B. 2017. Effect of Weed Management Practices in Chrysanthemum (Dendranthema grandiflora T.) Under Tarai Conditions of Uttarakhand. Int.J.Curr.Microbiol.App.Sci. 6(8): 3028-3034. doi: https://doi.org/10.20546/ijcmas.2017.608.362 